\title{
Engagement and Performance among Administrators of Public Secondary School in Nakhon Nayok, Thailand
}

\author{
Rohamina Palakad Gapor ${ }^{1} \&$ Teresita Rubang Doctor ${ }^{2, *}$ \\ ${ }^{1}$ Faculty of Education, St. Theresa International College, Ongkharak, Nakhon Nayok, Thailand \\ ${ }^{2}$ St. Theresa International College, Ongkharak, Nakhon Nayok, Thailand \\ *Correspondence: St. Theresa International College, Ongkharak, Nakhon Nayok, Thailand. Tel: 66-949-091-158. \\ E-mail: tessdoctor@stic.ac.th
}

Received: August 12, 2020

Accepted: September 5, $2020 \quad$ Online Published: October 10, 2020

doi:10.5430/wje.v10n5p29

URL: https://doi.org/10.5430/wje.v10n5p29

\begin{abstract}
This study used a descriptive-quantitative research method. The objectives were to assess administrators' level of work engagement, work performance, and to determine the correlation between work engagement and work performance. The respondents of this study were 22 principals/deputy principals, 22 directors/deputy directors, and one hundred seventy-six (176) department heads and deputy department heads of the public secondary schools of Nakhon Nayok, Thailand. All data were based on a self-report. The findings showed that the administrators' engagement level (mean $=4.07)$ and performance level (4.21) was high at a 0.5 level of significance. There is also a strong correlation $(\mathrm{r}=0.96)$ between engagement and performance. The implication of this study is to help administrators maintain or enhance engagement and performance for continuous improvement in the indicators mentioned in this study for the success of school management.
\end{abstract}

Keywords: administrators, work engagement, work performance, Nakhon Nayok

\section{Introduction}

\subsection{Background of the Study}

Over the past years, employee engagement and performance are fundamental keys to organizational success. Employee engagement is gaining momentum, popularity, and acquiring international attention. It becomes an accepted belief that engaged employees feel connected to their work, positively influencing their performance. Thayer (2008) supported the idea that employee engagement is an essential tool in organizational success. By knowing the factors that can help increasing employee engagement, employers can make a plan or strategy within their organizations to create a conducive and favorable psychological climate. In an interview by Amabile, (Forbes, 2014) mentioned that managers should help people find meaning in their work to get engaged. Recognition of employees can make employees more engaging. According to Russell (2010), recognition does not often happen in the workplace, even though it is vital to employees and makes a difference to the company's bottom line. If the leaders who take the time to recognize staff make a difference in their lives and success.

More recently, administrators are trying to assess the employees using some tools to strengthen engagement and performance to do their job effectively. Researchers showed that administrators could identify the factors that influence the employees' level of engagement and performance. Numerous reports identified worldwide the employees' low level of engagement. Only fifteen percent [15\%] of workers can be described as fully engaged in their work, while eighty-five percent [85\%] are not engaged or are actively disengaged (Gallup, 2017). Furthermore, Gallup identified three (3) types of engagement; engaged, not engaged, and actively disengaged employees. Engaged employees are the builders who regularly give the best at work. Not engaged employees are focus only on the tasks spelled out to them rather than the organization's goals. The worst type of engagement is disengaged employees. These employees are dangerous. They do not perform well and demotivate or discourage the organization's performance. The academic community also sees the problem of low employee engagement and its negative impact on business outcomes (Motyka. B., 2018). Engagement refers to the commitment of the employee to the organization's goals and values. A satisfied employee might show up for work daily without complaint but will not put extra effort on her own 
(Kruse, 2011). Satisfaction and commitment are correlated with performance, but engagement is generally a better predictor of employee performance. West and Dawson (2012) mentioned that researchers measured employee engagement over the past years using three approaches: a description of conditions under which people work, behavioral outcomes, and psychological orientation. This approach to engagement is the most common in academic research to date.

However, employee engagement should not be confused or used interchangeably with commitment. Organizations must work to engage employees and establish a two-way relationship between the employer and employee (Robinson et al., 2005). Engaged employees are motivated to contribute knowledge and skills to organizational success, and are able at the same time to enhance their sense of well-being. Chiumento (2004) described engagement as a positive and two-way relationship between an employee and the organization. Another aspect of human resources, which is essential to note, is employee performance. Performance is the activities expected to a worker and how well those activities are done (Dessler, 2012). Armstrong (2006) defines performance as the accomplishment of the quantified objectives of employees. The function of performance is both ability and motivation. To unlock employees' true potential and productive work, administrators or managers must align their jobs to their goals, values, and objectives. Layne (2019) mentioned that organizations assess their workforce's performance on an annual or quarterly basis to identify areas for improvement. Many studies had emphasized that the vital way to enhance employee performance is to focus on fostering employee engagement. Managing daily employee performance is the key to a compelling performance in the management system. Performance appraisal is one of the most known or popular tools used by organizations and businesses to achieve their employees' desired performance (Layne, 2019). Organizations should provide managers with enough training to find the right solutions that address the employees' poor performance. The best approach is based on the assumption that people who care will tend to improve the facilities around them and work hard for the success of the organization (Tumarkin, 2019).

Due to the above premise, the researcher is guided to look into employee engagement and performance. The researcher wanted to measure engagement and performance among administrators of Secondary Public Schools in Nakhon Nayok. Also, to determine areas that need to improve for the success of school management.

\section{Objectives of the Study}

This research wanted to study the engagement and performance level of administrators in Nakhon Nayok Public Secondary Schools. Specifically, it aimed to:

1. assess the level of engagement and performance, and

2. determine the correlation between work engagement and work performance.

\section{The Paradigm of the Study}

\begin{tabular}{|c|c|c|}
\hline $\begin{array}{l}\text { ENGAGEMENT } \\
\text { - Manager/ supervisor evaluation } \\
\text { - Teamwork } \\
\text { - Growth opportunities } \\
\text { - Work-Life balance } \\
\text { - Behavioral fairness } \\
\text { - Effective communication }\end{array}$ & & $\begin{array}{l}\text { PERFORMANCE } \\
\text { - Job knowledge } \\
\text { - Interpersonal skills, cooperation/ } \\
\text { collaboration } \\
\text { - Communication skills } \\
\text { - Planning organizing and achieving } \\
\text { results } \\
\text { - Problem analysis and decision } \\
\text { making } \\
\text { - Commitment to diversity/ inclusion }\end{array}$ \\
\hline
\end{tabular}

\section{Literature Review}

Kahn (1990) mentioned that employee engagement theory is a construct that is a personal expression of self-in role; engaged employees express willingness to invest skills, knowledge, and energy in an organization. Kahn was the first to define employee engagement as the harnessing of organization members' selves to their work roles. Employee engagement is also defined as the participation, satisfaction, and eagerness of individuals for work (Harter et al., 2002). Employee engagement is also a popular concept in the industry from 1999- 2005 and discussed the importance of 
employee engagement among managers, consultants, and policymakers. In engagement, people are hired based on their physical, cognitive, and emotional role during the performance. Academicians became interested in the concept of employee engagement. Several studies extended this idea into job engagement, work engagement, and organization engagement (Welch, 2011). The precursor of employee engagement were job characteristics, organizational support, supervisor support, rewards, recognition, procedural justice, and distributive justice. On the other hand, the consequences of engagement were job satisfaction, organizational commitment, intention to quit, and organizational citizenship behavior. Numerous studies propose that employees with a high level of engagement in the organization significantly reduce turnover intention (Maslach et al., 2001; Saks, 2006). Gallup, a known authority on employee engagement, connect employee engagement to a positive employee's emotional attachment and commitment (Demovsek D, 2008). Thus, employee engagement makes employees emotionally attached to their organization and becomes passionate about their work; hence, it improves employee retention. Employee engagement is a crucial reason for fostering high employee performance levels shown in several studies (Macey et al., 2009; Mone and London, 2019). Performance management sets meaningful goals that build trust between employers and employees to enhance employee engagement.

Additionally, Crabb (2011) supported the idea that work engagement is a positive attitude of the employee regarding its values. His research focused on employees' engagement and awareness of colleagues' business context and worked to improve the organization's job performance. Moreover, the organization must develop an engagement level that requires two-way relationships between employer and employee.Research conducted by Mone, E.M. et al. (2011) addresses the sense of employee engagement and evident to others through the presence of personal initiative, adaptability, effort, and persistence directed toward the organization's goals. It is also a relatively new concept that needs to promote a desirable performance (Macey \& Schneider, 2008). The factors that build engagement may differ from traditional employees' results, such as job satisfaction and organizational commitment (Macey et al., 2009). The considerations of promoting engagement as a desirable outcome of the performance management process constitute relevant development in the performance (Sparrow, 2008). Furthermore, Linley et al. (2009) noted that employee engagement represents a practical approach. Thus, consideration of how employee engagement provides to performance management is a progress in the performance management literature that is consistent with recent organizational sciences trends.

Studying employee engagement may strengthen performance beyond that achievable through a current focus on the performance itself. The traditional approach to performance assessment applies to stable jobs. The process of work is procedural and observe easily (Banks and May, 1999). However, Singh (2008) mentioned that current jobs are much less static, and job represents excellent performance is more variable (Fletcher \& Perry, 2001). Additionally, the complex and dynamic nature of performance is captured by distinguishing between the task and the evolution of concepts such as emotional intelligence (Goleman, 1998), contextual performance (Borman \& Motowildo, 1993). Engaged employees feel concerned about their organization and work to contribute towards its success. According to Gallup (2005), he observed that highly engaged employees are assets for an organization to attract more talented people while disengaged employees are a liability to the organization due to lower productivity and higher absenteeism, recruitment, and training cost.

The following literature below reviewed the specific indicators of work engagement and performance.

\subsection{Manager/Supervisor Evaluation}

According to Mahazril et al. (2012), rewards, recognition, and communication can motivate the employees to work efficiently and effectively. Recognition is one of the motivations that increase the level of productivity and the job performance of employees. Furthermore, Mahazril et al. (2012) emphasized that employees' performance must appreciate by the organization from time to time and offer other benefits, such as payment, which motivate the employees to work.

\subsection{Teamwork}

Teamwork is an essential factor for the smooth functioning of an organization. One research study concluded that teamwork is an essential tool for all organizations, including non-profit organizations (Pfaff \& Huddleston, 2003). Any organization needs to cooperate for their work and share relevant information with teammates and supervisors. Good teamwork enables people to cooperate in the work, enhance skills, and provide feedback without conflict between individuals (Jones et al., 2007). Collaboration is a strategy that can lead to the enhancement of employees' performance in an organization that needs to support (Ingram, 2000). According to Conti and Kleiner (2003), teams provide substantial cooperation, challenges, and feelings of accomplishment in organizations. These kinds of teams attract or engage the best people to stay in the organization. In turn, it will create a flexible, efficient, profitable, and high level of 
performance. When teams cooperate, their knowledge and skills improve without conflict (Jones et al., 2007; Froebel \& Marchington, 2005).

\subsection{Work-Life Balance}

High quality work is a feature of high-performance work systems. Factors influencing the life balance and quality of work include workload, management practices, work environment, and the organizational work-life balance initiatives (Karasek and Theorell 1990) and autonomy (Parker and Wall, 1998). These factors influence the engagement and performance of employees to do work. A work/life balance survey conducted in 2002 by True Careers revealed that $70 \%$ of more than 1,500 respondents said they do not have a healthy balance between their personal and work lives. According to Kanaka (2012), a stress-free environment means the employees work harmoniously and put their best efforts on their job. Most people working in a relaxing atmosphere feel good, which helps them to improve performance.

\subsection{Behavioral Fairness}

Konrad (2006) suggests that employees' high-involvement in a workplace develops positive beliefs and attitudes that create discretionary, leading to employees' high-performance work practices. The information about how actions affect engagement can able to identify and improve the performance of employees. Commitment is one-step to strengthen engagement based on the IES Research report. Understanding engagement and factors affecting it is an essential element in an organization's interests to improve engagement. The most reliable driver identified in the research is a sense of feeling valued and involved (Robinson et al., 2004). Additionally, managers must remember the individual differences for them to fulfill their work. Rewards are also significant for individual needs to recognize their effort contributed to the organizations. Many employees seek recognition, motivation, autonomy, flexible working schedules, and advancement opportunities to their employer. In order to understand employee's individual needs, managers must look for the factors influencing their behaviors and work to fulfill these needs in useful ways.

Deborah Rupp, an industrial-organizational psychologist, mentioned the concept of workplace fairness affecting employees' physical and emotional health that has an impact on the organization. At the same time, fairness perception builds engagement, faithfulness, and a sense of well-being. The feeling of injustice can create spark hostility, aggressiveness, ineffective work, absenteeism, and quitting a job (Tricoles, 2012). The purposes of fairness are crucial to develop a sense of trust. According to Swarnalatha and Prasanna (2013), fairness and other related elements can strengthen employee engagement while unfairness can weaken employee engagement. A vital variance when dealing with engagement is whether it is a state or behavior. Some studies consider engagement to be a state while others describe it as a psychological state with behavioral manifestations (Schaufeli et al., 2002). The state of engagement indicates the mental presence that covers attentiveness, connected, integrated, and focused. Furthermore, these are indicated in terms of physical, cognitive, emotional behaviors, or personal engagement (Kahn, 1992). Kahn's model found the effectiveness of personal engagement to improve the performance outcomes of the employees. More recently, Macey et al. (2009) characterized engagement in terms of employee engagement feelings, consisting of opinions of urgency, focus, intensity, enthusiasm, and behaviors.

Furthermore, Macey et al. (2009) present a model of the employee engagement value chain in which engagement feelings and engagement behaviors lead to performance outcomes. The excellent practice would show up if the employee feels that they belong and their work is appreciated. They also need to listen to the opinions of others for the success of their work. Ethical behavior must also develop to show integrity, honesty, responsibility, and loyalty in the performance tasks.

\subsection{Effective Communication}

Communication is a process of educating and motivating employees to support the organization (Barrett, 2002). Good communication requires a degree of cognitive organizational reorientation. An example is understanding and acknowledges the proposed changes for employee improvement (Van Vuuren \& Elving, 2008). The most important conclusion drawn from interview research between management and employees was the successful organization and managers' role to communicate effectively with the employees at all levels (Elving and Hansma, 2008). Managers must be aware of change within the organization (Bolden \& Gosling, 2006), and the problem of communication should be addressed (Lewis, 2000). Communication plays an essential role in having effective communication between employees and management. The multiplier approach is the most commonly used approach for effective communication during organizational change. The multiplier approach's concept is for employees to make ready from different units and levels relating to a specific change.

Furthermore, a multiplier approach is suitable for changing an organization's elements, such as strategy, structure, 
systems, and processes (Wagner, 2008). According to Harris \& Nelson (2008), communication is an essential activity in organizations established and run by influential people. Some of these are noticed and visible to the public but unseen in the organization. They work behind the scenes. When change occurs in an organization, these hidden and invisible people become central victims of the change process. Many people result in a loss of a job, early retirement, change of career, or become victims of downsizing. Therefore, to avoid negative feelings, internal communication between employees and management must develop (Proctor \& Doukakis, 2003). The communication competence, quality, styles, and channels of a leader can influence employees' attitudes and behavior (e.g., Snyder \& Morris, 1984; Shaffer, 2000). Employees who are not sure about their organization's roles due to ineffective communication can cause role ambiguity, role conflict, and interpersonal conflicts (Suzy et al., 2001). On the other hand, effective communication is necessary to expand and convey information appropriately to all individuals, supervisors, and co-workers. The employee used a clear and concise language to provide accurate written and oral communication. Organizational capabilities are developed and enacted intensely through social and communicative processes (Jones et al., 2004).

Moreover, communication helps individuals and groups to have socialization, decision-making, problem-solving and change-management processes. If there is effective communication and effective time management, the schedule will be met. The employee accurately estimated the time required to complete a task to meet assigned deadlines. Employees should have the ability to solve the problem, suggest alternatives and creative solutions, and assess consequences.

\subsection{Performance}

Organizational performance is now seen as multidisciplinary and socially constructed (Herman \& Renz, 1997). Performance can be assessed in terms of goal accomplishment, efficiency or cost-effectiveness, acquisition of critical resources (e.g., funding), environmental adaptation, a satisfaction of key stakeholders (e.g., board members, regulators, funding sources), and internal processes (e.g., organizational learning, staff morale, and corporate culture). Management outcomes are reflected in financial health and employee satisfaction (Sowa, Selden, \& Sandfort, 2004). Program performance is described in terms of outputs, outcomes, productivity, and quality to determine factors affecting organizational performance in human services. It is a challenging and essential field of study for decades (Patti, 1987; Schalock \& Bonham, 2003; Stone \& Cutcher-Gershefeld, 2001). The importance of performance and accountability in human services has been discussed in the literature.Accountability refers to the employee who demonstrates responsibility to complete the tasks. It recognizes how the performance affects goals, objectives, work, plans, issues, and innovative approaches to resolved issues.

\subsection{Job Knowledge}

Excellence in service must demonstrate by the employee for the success of the organization. The employee must be affectionate, responsive, and welcoming to constituents and co-workers they serve. The employees feel a sense of purpose and achievement if their jobs are recognized (Kahn, 1990). Most employees want to make contributions to the organization regardless of position. They want to be challenged to meet high standards, even in difficult situations (Cartwright and Holmes, 2006). The most competent managers set challenging yet attainable goals for the employees to work hard and reach their goals. However, to motivate and achieve goals, employees need to understand what is expected of them and how their jobs benefit their success.

\subsection{Interpersonal Skills, Cooperation, and Collaboration}

Gallup (2011, p. 14) mentioned the educational opportunities that address employees' development, which may include formal classes or finding new experiences to take on. Collaborative organizations are characterized by having a collective identity, centralized integrative configurations, control practices, and incentive systems that reward organizational performance instead of individual performance (Houston et al., 2001; and Birkinshaw, 2001).

\subsection{Communication Skills}

Upadhyay and Gupta (2012) emphasized the importance of communication in increasing employees' satisfaction at work. Many organizations host open forums that allow employees to share knowledge, post questions to the management teams, and receive feedback to assist effective communication. Open forums enable employees to become honest, minimize hearsay, and distrust (Argenti and Forman, 2004). More importantly, feedback can help manage a better understanding of the employees' needs. To maintain trust during stressful periods such as layoffs, top managers must communicate effectively with the employees to provide well-developed reasons that treat employees in a dignified and respectful manner (Folger and Skarlicki, 1998; Dirks and Skarlicki, 2004). Mwangi and Waithaka (2018) recommended that departments be harmonized and structured correctly for effective communication among university departments. Further, it suggests the presence of a clear policy on communication procedures. 


\subsection{Planning, Organizing and Achieving Results}

Planning and organizing skills help manage the time, tools, and resources to reach a goal. Planning is essential at all levels. Without planning and organizing, they would confuse, nothing gets done, and everything would be difficult. Planning facilitates the combination of goals into people's behavior (Bandura, 1997). It is supported by (Nuttin 1984), who stated that planning helps people create instrumental thoughts about the desired future. Moreover, planning is one of the necessary skills to achieve goals.

\subsection{Problem Analysis and Decision}

Problem-solving and decision-making are interrelated. The problem cannot solve without making a decision. There are two main types of decision-makers. Some people use a systematic, rational approach; others are used more intuitive. They go with their emotions or feeling about the right path. They may have highly creative ways to address the problem, but cannot explain why they have chosen this approach. Problem-solving involves decision-making; this is essential, especially for management and leadership. There are processes and techniques to enhance decision-making and the quality of decisions. Decision-making is more natural to individual personalities, so these people should focus more on improving the quality of their choices. People that are fewer logical decision-makers are often able to make quality assessments, and this assessment needs to be more decisive.

\subsection{Commitment to Diversity / Inclusion}

May et al. (2004) conducted research that described employee relationships with co-workers and supervisors that affect employees' psychological conditions. The research showed that having a good relationship developed a sense of belonging and commitment to the employees. Appreciation from co-workers and supervisors create a feeling of satisfaction of employees in the workplace. The employee must feel a favorable condition in work to be more committed. Research antecedents of the engagement are group into two approaches: those related to work (Schaufeli \& Bakker, 2004) and are associated with psychological conditions (Kahn, 1990). Vuong et al. (2020) concluded that employees' high organizational commitment leads to high job performance.

\section{Related Studies}

In a research study by Halbesleben and Wheeler (2008) in the United States among supervisors and employees, work engagement had significant partial correlations with performance. Based on self-rating, supervisor rating, and co-worker rating, work engagement influence the performance of employees. Also, Kirk-Brown and Dijik (2011) established a positive relationship between work engagement and work performance in Australia's employees using self-report measures and psychological safety as a mediating variable.

In the European workforce, some research showed a positive relationship between work engagement and work performance. The study of Dutch workers, Bakker and Demerouti (2009), showed the positive relationship between men's work engagement related to employees' role and extra-role performance. Women's work engagement also had a relevant effect on men's job performance through men's work engagement. Furthermore, researchers showed that administrators could know the factors that influence employees' engagement and performance. Gorgievski et al. (2010) research study in some of the Netherlands' employees revealed the significant relationship between work engagement and job performance.

Similarly, Balducci et al. (2010) investigate the relationship between work engagement and work performance in two samples of Italian and Dutch white-collar employees. The study found out the positive connection between work engagement and work performance using self-report. Additionally, Bakker and Bal (2010) also studied the relationship between weekly work engagement and performance. Moreover, Bakker et al. (2012) examined the relationship between work engagement and performance. The moderating role of conscientiousness in employees in the Netherlands work engagement was positively related to contextual performance and task performance, especially among employees with high conscientiousness. Robertson et al. (2012) emphasized the relationships among employee engagement, psychological well-being, and employee performance in the United Kingdom. Then study determine that employees' performance (productivity) was a good envision by a combination of psychological well-being and employee engagement than employee engagement alone. Similarly, Christian et al. (2011) noted that an engaged employee is more dedicated to physical, cognitive, and emotional resources, leading to a high-performance level. However, the knowledge of engagement's uniqueness as a predictor of job performance is less.

In Thailand, Mongkolworakitchai, N. (2016) studied the relationship between the director's leadership and teachers' high performance and engagement. The study showed the positive impact of the director's relationship with the engagement of teachers. Also, Smithikrai, C. (2019) found out that positive orientation, career satisfaction, and attitude 
toward organization are related to work engagement. The results indicate the work engagement, proactive work behavior, innovative work behavior, and organizational citizenship behavior.

All the previous studies mentioned above were done among employees not related to the school setting, and the subjects of the study were not administrators. This present study concentrated on engagement and performance among administrators of public secondary schools in Nakhon Nayok. Moreover, this research determines the significant correlation between engagement and performance.

\section{Methodology}

\subsection{Population and Data Collection}

The study was conducted in the secondary schools of Nakhon Nayok in Thailand's central region. The study included all the administrators of the Public Secondary schools of Nakhon Nayok in the academic year 2019 - 2020. The data gathered in February and March 2020. There are twenty-two (22) principals and deputy principals, twenty-two (22) directors and deputy directors, and one hundred and seventy-six (176) department heads and deputy department heads.

\subsection{Research Instrument}

A self-constructed and self-administered questionnaire in a checklist format was used to draw out the data. The tool was translated into the Thai language and validated by three (3) experts. The reliability is 0.956 using Cronbach alpha.

\subsection{Measures / Treatment of Data}

Summarized and tabulated data were analyzed using statistical tools in the SPSS. The statistical tool to answer the first problem was the computed mean of engagement and performance level based on a five-point Likert scale. The second problem was tested using the Pearson correlation.

\section{Results and Discussion}

The engagement level was measured according to the indicators, including supervisor evaluation, teamwork, growth opportunities, work-life balance, behavioral fairness, and effective communication. The job performance level was also measured using the following indicators: job knowledge, interpersonal skills, cooperation and collaboration, communication skills, planning, organizing and achieving results, problem analysis, and commitment to the work. Furthermore, the engagement level and performance level were correlated.

Table 1. The data showed that administrators' work engagement level in public secondary schools in Nakhon Nayok has an overall mean of 4.07. The following indicators, namely, teamwork, supervisor evaluation, effective communication, and growth opportunities, have a mean of greater than 4.0, which is high. However, the administrators rated themselves less than 4.0 in behavioral fairness and work-life balance, but the result still belongs to a high level. So, means the level of engagement among administrators in a public secondary school in Nakhon Nayok is high (4.07).

Table 1. Engagement Level of Administrators

\begin{tabular}{|c|c|c|}
\hline Engagement & Mean & Level of Engagement \\
\hline Supervisor Evaluation & 4.10 & High \\
\hline Team Work & 4.22 & High \\
\hline Growth Opportunities & 4.07 & High \\
\hline Work-life Balance & 3.95 & High \\
\hline Behavioral Fairness & 3.97 & High \\
\hline Effective Communication & 4.10 & High \\
\hline Grand Mean & 4.07 & High \\
\hline \multicolumn{2}{|c|}{ Exact Limits } & Level of Engagement \\
\hline \multicolumn{2}{|c|}{$4.5-5.0$} & Very high \\
\hline \multicolumn{2}{|c|}{$3.5-4.49$} & High \\
\hline \multicolumn{2}{|c|}{$2.5-3.49$} & Fair \\
\hline \multicolumn{2}{|c|}{$1.5-2.49$} & Low \\
\hline \multicolumn{2}{|c|}{$1.0-1.49$} & Very low \\
\hline
\end{tabular}


The results showed that the indicators of engagement obtained high self -assessment. It indicates that the administrators recognized that they are doing well in the different indicators of engagement.

However, administrators should pay attention to employees' behavioral fairness and life-work balance because they got the lowest self-assessment report of below 4.0. In terms of manager or supervisor evaluation, Mahazril et al. (2012) emphasized the importance of recognizing employees from time to time and offering other benefits, such as a payment to help them motivated. Apart from supervision, rewards, recognition, empowering employees, and building bonds between leaders and employees are essential. (Osborne and Mohammad, 2017).

Ravikumar (2013) mentioned the significant impact of teamwork on the engagement level of employees. Swarnalatha and Prasanna (2013) concluded that employee engagement could be strengthened by fairness and other related elements while showing unfairness to the employees can weaken the engagement. Bai, J \& Liu, J. (2018) found that employees' career growth opportunities positively affect work engagement. Further, they found that career growth and work engagement are partly mediated by organizational identification, which shows that growth opportunities are an indicator of engagement.

According to Froebel \& Marchington (2005), team members enhance their competency, knowledge, comprehension, and abilities while working in teams. Teamwork helps improve the quality of work and empowers employees in their job training related to problem-solving skills (Evans, 2005). These employees are actively seeking opinions and feedback from others for a better output. In teamwork, effective communication is significant in understanding each other. Harris and Nelson (2008) determine the importance of communication as a relevant activity and the most dominant to formulate ideas and build a strong foundation.

Additionally, fairness in dealing with employees improve employee engagement (McManus, 2015). However, employees who are not dedicated to work lead to unsuccessful organizations. Finally, Larasati \& Hasanati (2019) concluded that work-life balance influences employee engagement.

Table 2 shows that the performance level of administrators of public secondary schools in Nakhon Nayok has an overall mean of 4.21, which is high. The study revealed that administrators rated themselves high in job knowledge, interpersonal skills/cooperation/collaboration, communication skills, planning/organizing/ achieving results, problem analysis/decision making, and employee commitment. Ayman et al. (2018) denoted that job knowledge significantly influence job performance. Job knowledge is proof that employees and administrators must know the nature of work given to them for their better output and success. Most people wish to have a contribution to that organization (Cartwright and Holmes, 2006). In terms of interpersonal skills, cooperation, and collaboration, administrators showed a high level of performance. Collaboration refers to individuals in organizations working together. The administrators also rated themselves high in terms of communication.

Table 2. Performance Level of Administrators

\begin{tabular}{|c|c|c|}
\hline Performance & $\begin{array}{l}\text { Mean } \\
\text { performance }\end{array}$ & Level of \\
\hline Job knowledge & 4.25 & High \\
\hline Interpersonal Skills/cooperation/Collaboration & 4.32 & High \\
\hline Communication skills & 4.21 & High \\
\hline Planning/organizing/achieving results & 4.15 & High \\
\hline Problem Analysis/decision making & 4.14 & High \\
\hline Commitment & 4.20 & High \\
\hline Grand Mean & 4.21 & High \\
\hline Exact Limits & & Level of Performance \\
\hline $4.5-5.0$ & & Very high \\
\hline $3.5-4.49$ & & High \\
\hline $2.5-3.49$ & & Fair \\
\hline $1.5-2.49$ & & Low \\
\hline $1.0-1.49$ & & Very low \\
\hline
\end{tabular}

The communication is very crucial for organizations (Holtzhausen, 2002). Communication is essential in coordinating activities to achieve goals, decision-making, and problem-solving. Clear and concise language is vital for effective communication to strengthen the employees' ability to reach organizational goals (Hindi et al., 2004). When effective communication developed and led to high commitment (4.20), as shown on the table. Guest et al. (2003) emphasize the 
need to establish an organizational commitment among employees that leads to positive outcomes such as low labor turnover, less absenteeism, motivated, and improved performance. Moreover, commitment is a human relation concept generating human energy and activating the human mind (Jaw and Liu, 2004).

The administrators also revealed that their performance level in solving a problem and making effective decision-making was high (4.2). Problems are difficult to explain without making a decision. Problem-solving and decision-making are interrelated that require understanding in solving the problem. People that are fewer logical decision-makers need to be more conclusive in addressing problems that deliver outcomes effectively achieved by working alone (Keast \& Mandell, 2009). Additionally, Gallup (2011) supported the idea of providing administrators and employees educational opportunities for their development in terms of interpersonal skills and cooperation or collaboration.

\subsection{Correlation of Work Engagement and Work Performance}

Table 3 shows that administrators' work engagement level and work performance level in public secondary schools in Nakhon Nayok has a high correlation coefficient of $r=0.9599 \mathrm{p}=0.00001$, and .05 level of significance. The data revealed that administrators' engagement and performance were significantly correlated in all indicators. Teamwork and interpersonal skills/cooperation/collaboration were high and significantly correlated. The result emphasized that achievement and collaborative decision-making reflect team and co-worker relationships. This relationship takes a greater responsibility to achieve shared goals and visions. The relationship between teamwork and co-worker is also influential in employee engagement. Teamwork is defined as sharing vision, objectives, knowledge, depending on one another or pulling together for the organization (Aviva, 2006). Also, (USA Hockey, 2006) stated that cooperation encourages employees to benefit and succeed. Those fresh or new employees must guide them and develop collegial and professional skills (Hertzog et al., 2000). Supervisor evaluation and Job knowledge are also correlated. It means the managers greatly influence high organizational performance in handling their employees. The supervisor evaluated the job knowledge of employees effectively. An essential aspect of effective performance management is designing jobs and assigning work so that most of the employee's tasks require applying their competency strengths.

Table 3. Correlation of Engagement and Performance

\begin{tabular}{llll}
\hline Engagement & Mean & \multicolumn{1}{c}{ Performance } & Mean \\
\hline Supervisor Evaluation & 4.10 & Job knowledge & 4.25 \\
Team Work & 4.22 & Interpersonal Skills/cooperation/Collaboration & 4.32 \\
Growth Opportunities & 4.07 & Communication skills & 4.21 \\
Work-life Balance & 3.95 & Planning/organizing/achieving results & 4.15 \\
Behavioral Fairness & 3.97 & Problem Analysis/decision making & 4.14 \\
Effective Communication & 4.10 & Commitment & 4.20 \\
Grand Mean & 4.07 & & 4.21 \\
$\mathrm{r}=0.9599$ & & & \\
$\mathrm{p}=0.00001$ (.05 level of significance) & & & \\
\hline
\end{tabular}

The table also revealed that communication and commitment among administrators are high and significantly correlated. Mayfield and Mayfield (2007) stated that employee commitment is an essential leadership measure for its success. The employee commitment towards work strengthens organizational performance. Effective communication establishes a connection to enhancing the professional growth of employees. Training and development practices are beneficial ways to acquire new knowledge and skills to meet competitive standards (Tsai and Tai, 2003). Kalleberg and Rognes (2000) noted the importance of developing professional skills to the employees' turnover. Moreover, Hwang and Kuo (2006) found a significant positive correlation between perceived alternative job opportunities and turnover intention in public sector organizations.

However, Behavioral fairness and work-life balance have a Mean of less than 4:0 but more significant than 3.5. The result still belongs to a high level of engagement and performance. Therefore, behavioral fairness is significantly correlated with problem analysis/decision making and the work-life balance with planning/organizing/achieving results. Employee engagement is a more valid predictor of positive organizational performance.

Concerning the study results, some related studies have found a significant correlation between engagement and performance. In a research study of Halbesleben and Wheeler (2008) in the United States among supervisors and employees, they found the significant partial correlations of work engagement and performance. Based on a self-rating, supervisor rating, and co-worker rating, work engagement influences employees' performance. Kirk-Brown and Dijik 
(2011) study a positive relationship between work engagement and work performance in Australia's employees using self-report measures and psychological safety as a mediating variable.

In the European workforce, some research showed a positive relationship between work engagement and work performance. The study of Dutch workers, Bakker and Demerouti (2009), showed the positive relationship between men's work engagement related to employees' role and extra-role performance. Women's work engagement also had a relevant effect on men's job performance through men's work engagement. More recently, administrators are trying to assess the employees using some tools to strengthen engagement and performance to do their job effectively. Researchers showed that administrators could able to know factors that influence the engagement and performance of employees. Moreover, Gorgievski, Bakker, and Schaufeli (2010) research study in some of the Netherlands' employees revealed the significant relationship between work engagement and job performance.

Similarly, Balducci, Fraccaroli, and Schaufeli (2010) investigate the relationship between work engagement and work performance in two samples of Italian and Dutch white-collar employees. The study found out the positive connection between work engagement and work performance using self-report. Additionally, Bakker and Bal (2010) also studied the relationship between weekly work engagement and performance. Moreover, Bakker, Demerouti, and Brummelhuis (2012) examined the relationship between work engagement and performance. The moderating role of conscientiousness in employees in the Netherlands work engagement was positively related to contextual performance and task performance, especially among employees with high conscientiousness. Robertson, Birch, and Cooper (2012) emphasized the relationships among employee engagement, psychological well-being, and employee performance in the United Kingdom. Then study determine that employees' performance (productivity) was a good envision by a combination of psychological well-being and employee engagement than employee engagement alone. Similarly, Christian et al. (2011) noted that an engaged employee is more dedicated to physical, cognitive, and emotional resources, leading to a high-performance level. However, the knowledge of engagement's uniqueness as a predictor of job performance is less.

In Thailand, Mongkolworakitchai, N. (2016) studied the relationship between the director's leadership and teachers' high performance and engagement. The study showed the positive impact of the director's relationship with the engagement of teachers. Also, Smithikrai, C. (2019) found out that positive orientation, career satisfaction, and attitude toward organization are related to work engagement. The results indicate the work engagement, proactive work behavior, innovative work behavior, and organizational citizenship behavior.

\section{Conclusion}

Assessment of administrators' engagement and performance in a school setting is essential to monitor their level of engagement and performance because it directly affects the effectiveness of the school that they manage. Based on the study results analysis, the researcher concluded that there is a high level of administrator engagement and performance, and there is a high correlation of engagement and performance among the administrators of the public schools in Nakhon Nayok, Thailand. This result is collaborated by a recent survey by Qualtrics (Bangkok, 3 February 2020) that Thai workers have a higher engagement level (72\%) compared to the global average (53\%). According to the same survey, only $8 \%$ of Thai employees tend to change jobs within one year. Most employees stay in their jobs for a more extended period, and that asking for employee feedback, frequency, and immediate response to increases engagement and performance.

Further, it was found out that highly engaged employees are more likely to exceed performance expectations. Therefore, among the top drivers of employee engagement in Thailand are recognition for good work, a clear link between the work, the organization's strategic objectives, opportunities for learning and development, and managers who help employees with careers. Therefore, it is safe to mention that an engaged administrator performs better and will influence the school's performance as a whole.

\section{Recommendation}

Based on the study results, the researcher recommends regular measuring engagement and performance levels among themselves and new administrators, to determine if any indicators need improvement. Moreover, the administrators in the public schools in Nakhon Nayok should maintain or continuously improve their high engagement and performance for excellent school performance. The researcher also recommends future research to pursue a similar study that will delve deeper into the details of the factors influencing the administrators' and teachers' work-life balance and behavioral fairness. 


\section{References}

Amabile, T. (2014). Interview by Karl Moore. Forbes.

Argenti, P. A., \& Forman, J. (2004). The Employee Care Revolution. Leader to Leader, 33, 45-52. https://doi.org/10.1002/lt1.88

Armstrong, M. (2006). A Handbook of Human Resource Management Practice (10th ed.). Kogan Page Publishing: London.

Aviva (2006). Teamwork. Retrieved 2 December, 2006 from http://www.aviva.com

Ayman. A. S. Almusaddar, S., Ramzan, R., \& Raju, V. (2018). The influence of knowledge, satisfaction, and motivation on employee performance through competence. International Journal of Business and General Management (IJBGM), 7(5), 21-40.

Bai, J., \& Liu, J. (2018). Study on the influence of career growth on work engagement among new generation employees. Open Journal of Business and Management, 6(2), 300-317. https://doi.org/10.4236/ojbm.2018.62022

Bakker, A. B., \& Bal, P. M. (2010). Weekly Work Engagement and Performance: A Study among Starting Teachers. Journal of Occupational and Organizational Psychology, $83, \quad 189-206$. http://dx.doi.org/10.1348/096317909X402596

Bakker, A. B., \& Demerouti, E. (2009). The crossover of work engagement between working couples: A closer look at the role of empathy. Journal of Managerial Psychology, 24(3), 220-236. http://dx.doi.org/10.1108/02683940910939313

Bakker, A. B., Demerouti, E., \& Brummelhuis, L. L. (2012). Work engagement, performance, and active learning: The role of conscientiousness. Journal of Vocational Behavior, 80, 555-564. http://dx.doi.org/10.1016/j.jvb.2011.08.008

Balducci, C., Fraccaroli, F., \& Schaufeli, W. B. (2010). Psychometric Properties of the Italian Version of the Utrecht Work Engagement Scale (UWES-9). European Journal of Psychological Assessment, 26(2), 143-149. http://dx.doi.org/10.1027/1015-5759/a000020

Bandura, A. (1997). Self-Efficacy: The Exercise of Control. W. B. Freeman and Company, New York.

Banks, C. G., \& May, K. E. (1999). Performance management: the real glue in organizations. In A. I. Kraut \& A. K. Korman (Eds.), Evolving practices in human resource management (pp. 118-145). San Francisco, CA: Jossey-Bass.

Barrett, D. J. (2002). Change communication: using strategic employee communication to facilitate major change. Corporate Communications: An International Journal, $219-231$. http://dx.doi.org/10.1108/13563280210449804

Birkinshaw, J. (2001). Making Sense of Knowledge Management-What knowledge management is and is not. Ivey Business Journal, 65(4), 32-36.

Bolden, R., \& Gosling, J. (2006). Leadership competencies: Time to change the tune? Leadership, 2, $147-163$. https://doi.org/10.1177/1742715006062932

Borman, W. C., \& Motowidlo, S. J. (1993). Expanding the criterion domain to include elements of contextual performance. In N. Schmitt \& W. C. Borman (Eds.), Personal selection in organizations (pp. 71-98). San Francisco: Jossey-Bass.

Cartwright, S., \& Holmes, N. (2006). The Meaning of Work: The Challenge of Regaining Employee Engagement and Reducing Cynicism. Human Resource Management Review, 16, 199-208. http://dx.doi.org/10.1016/j.hrmr.2006.03.012

Chiumento (2004). Get Engaged. Chiumento: London.

Christian, M. S., Garza, A. S., \& Slaughter, S. J. (2011). Work Engagement: A quantitative review and test of its relations with task and contextual performance. Personnel Psychology, 64(1), 89-136. https://doi.org/10.1111/j.1744-6570.2010.01203.x

Conti, B., \& Kleiner, B. (2003). How to increase teamwork in organizations. Journal of Quality, 5(1), $26-29$.

Crabb, S. (2011). The use of coaching principles to foster employee engagement. The Coaching Psychologist, 7(1), 
27-34.

Demovsek, D. (2008). Employee retention through employee engagement. International Journal of Business and Management Invention, 2319-8028.

Dessler, G. (2012). Fundamentals of human resource management (2nd ed.). Boston: Pearson Education.

Dirks, K. T., \& Skarlicki, D. P. (2004). Trust in leaders: Existing research and emerging issues. Trust and distrust in organizations: Dilemmas and approaches, 7, 21-40.

Elving, W., \& Hansma, L. (2008). Leading organizational change: On the role of top management and supervisors in communicating organizational change. Paper presented at the annual meeting of the International Communication Association, Montreal, Quebec, May, 1-45.

Evans, J. R., \& Lindsay, W. M. (2005). The Management and Control of Quality (6th ed.). Singapore: Thomson South-Western.

Fletcher, C., \& Perry, E. L. (2001). Performance appraisal and feedback: A consideration of national culture and a review of contemporary research and future trends. In N. Anderson, D. S. Ones, Employee engagement 207H. K. Sinangil, \& C. Viswesvaran (Eds.), Handbook of industrial, work, and organizational psychology, 1, 127-144. Thousand Oaks, CA: Sage.

Folger, R., \& Skarlicki, D. P. (1998). When tough times make tough bosses: Managerial distancing as a function of layoff blame. Academy of Management Journal, 41, 79-87. https://doi.org/10.5465/256899

Forbes (2014). The Crisis in Worker Engagement: The 2 Things You Should Do about It. Retrieved 17 January, 2014 from

http://www.forbes.com/sites/karlmoore/2014/01/17/the-crisis-in-worker-engagement-the-2-things-you-should-d o-about-it.htm

Froebel, P., \& Marchington, M. (2005). Teamwork structures and worker perception: a cross national study in pharmaceuticals. International Journal of Human Resource Management, 16(2), 256-276. https://doi.org/10.1080/0958519042000311435

Gallup (2005). Employee Engagement: The Engagement side of the Human sigma Equation. Retrieved 13 August, 2010 from www.gallup.com

Gallup Consulting Company (2011). On Employee engagement- A leading indicator of financial performance. The Gallup Corporate website.

Gallup, I. V. (2011). Employee Engagement-A Leading Indicator of Financial Performance. Gallup corporate website, 9.

Gallup, Inc. (2017). State of the Global Workplace Report. Washington.

Goleman, D. (1998). Working with emotional intelligence. London: Bloomsbury.

Gorgievski, M. J., Bakker, A. B., \& Schaufeli, W. B. (2010). Work engagement and workaholism: Comparing the self-Employed and salaried employees. The Journal of Positive Psychology, 5(1), 83-96. https://doi.org/10.1080/17439760903509606

Guest, D. E., Michie, J., Conway, N., \& Sheehan, M. (2003). Human Resource Management and Corporate Performance in the UK. British Journal of Industrial Relations, 41(2), 291-314.

Halbesleben, J. R. B., \& Wheeler, A. R. (2008). The relative roles of engagement and embeddedness in predicting job performance and intention to leave. July 2008 Work and Stress, 22(3), 242-256. https://doi.org/10.1080/02678370802383962

Harris, T. E., \& Nelson, M. D. (2008). Applied organizational communication: Theory and practice in a global environment. New York: Lawrence Erlbaum.

Harter, J. K., Schmidt, F. L., \& Hayes, T. L. (2002). Business-Unit-Level relationship between employee satisfaction, employee engagement, and business outcomes: A meta-analysis. Journal of Applied Psychology, 87(2), 268-279. https://doi.org/10.1037//0021-9010.87.2.268

Herman, R., \& Renz, D. (1997). Multiple constituencies and the social construction of non-profit organization effectiveness. Non-profit and Voluntary Sector Quarterly, 26, 185-206. https://doi.org/10.1177/0899764097262006 
Hertzog, H. S., Pensavelle, M. T., \& Lemlech, J. K. (2000). Collegial relationships: what does it mean to be a colleague? Annual meeting of the American Educational Research Association, New Orleans, LA, 24-28 April, Reports - Research (143) - Speeches - Meeting papers (150).

Hindi, M., Miller, D. S., \& Catt, S. E. (2004). Communication and Miscommunication in Corporate America: Evidence from Fortune 200 Firms. Journal of Organizational Culture, Communications and Conflict, 8(2), 13-26.

Holtzhausen, D. (2002). The effects of a divisionalised and decentralised organisational structure on a formal internal communication function in a South African organisation. Journal of Communication Management, 6(4), 323-339. https://doi.org/10.1108/13632540210807152

Houston, M. B., Walker, B. A., Hutt, M. D., \& Reingen, P. H. (2001). Cross-unit competition for a market charter: The enduring influence of structure. Journal of Marketing, 65(2), 19-34. https://doi.org/10.1509/jmkg.65.2.19.18256

Hwang, I. S., \& Kuo, J. (2006). Effects of job satisfaction and perceived alternative employment opportunities on turnover intention: An examination of public sector organizations. Journal of American Academy of Business, $8(2), 254-259$.

Ingram, H. (2000). Linking teamwork with performance. Journal of Team Performance Management, 2(4), 5-10.

Jaw, B., \& Liu, W. (2004). Promoting Organizational Learning and Self-Renewal in Taiwanese Companies: The Role of HRM. Human Resource Management, 42(3), 223-241.

Jones, A., Richard, B., Paul, D., Sloane, K., \& Peter, F. (2007). Effectiveness of teambuilding in organization. Journal of Management, 5(3), 35-37.

Jones, E., Watson, B., Gardner, J., \& Gallois, C. (2004). Organizational communication: Challenges for the new century. Journal of Communication, 54(4), 722-750. https://doi.org/10.1111/j.1460-2466.2004.tb02652.x

Kahn, W. A. (1990). Psychological Conditions of Personal Engagement and Disengagement at Work. Academy of Management Journal, 33(4), 692-724. https://doi.org/10.2307/256287

Kahn, W. A. (1992). To be full there: Psychological presence at work. Human Relations, 45, 321-349. http://dx.doi.org/10.1177/001872679204500402

Kalleberg, A. L., \& Rognes, J. (2000). Employment Relations in Norway: Some Dimensions and Correlates. $J$. Organ. Behav, 21, 315-335.

Kanaka, M. L. G. (2012). Employee Engagement: A corporate boon, 10 ways for effective engagement. Advances in Management, 5(2), 64-65.

Karasek, R. A., \& Theorell, T. (1990). Healthy work: Stress, productivity, and the reconstruction of working life. Basic Books, New York.

Keast, D. R., \& Mandell, D. M. P. (2009). 'What is collaboration?' Australian Research Alliance for Children \& Youth. Effectiveness of teambuilding in organization. Journal of Management, 5(3), 35-37.

Kirk-Brown, A., \& Dijk, P. V. (2011). Safe to engage: Chronic illness and organisational citizenship behaviours at work. International Journal of Disability Management, 6(1), 1-9. https://doi.org/10.1375/jdmr.6.1.1

Konrad, A. M. (2006). Engaging employees through high-involvement work practices. Ivey Business Journal, 70(4), $1-6$.

Kruse, K. (2011, June 22). What is employee engagement? Retrieved from http://www.forbes.com/sites/centurylink/2014/08/29/why-its-time-to-consider42 hybrid-it-infographic/

Larasati, D. P., \& Hasanati, N. (2019, March). The Effects of Work-Life Balance towards Employee Engagement in Millennial Generation. In 4th ASEAN Conference on Psychology, Counselling, and Humanities (ACPCH 2018). Atlantis Press.

Layne, S. (2019). Job Descriptions as a Feedback Tool: A Quantitative Study to Improve Performance Appraisal Practices (Doctoral dissertation, Northcentral University).

Lewis, L. K. (2000). Communicating change: Four cases of quality programs. Journal of Business Communication, 37, 128-155. https://doi.org/10.1177/002194360003700201

Linley, P. A., Joseph, S., Maltby, J., Harrington, S., \& Wood, A. M. (2009). Positive psychology applications. In S. J. 
Lopez \& C. R. Snyder (Eds.), Oxford library of psychology. Oxford handbook of positive psychology (pp. 35-47). Oxford University Press. https://doi.org/10.1093/oxfordhb/9780195335446.001.0001

Macey, W. H., \& Schneider, B. (2008). The meaning of employee engagement. Industrial and organizational Psychology, 1(1), 3-30. http://dx.doi.org/10.1111/j.1754-9434.2007.0002.x

Macey, W. H., Schneider, B., Barbera, K. M., \& Young, S. A (2009). Employee Engagement: Tools for Analysis, Practice, and Competitive Advantage. Wiley Blackwell.

Mahazril, A. Y., Zuraini, Y. Z., Hafizah, H. A. K., Aminuddin, A., Zakaria, Z., Noordin, N., \& Mohamed, B. Z. (2012). Work motivation among Malaysian public servants. Asian Social Science, 8(12), 238-242. https://doi.org/10.5539/ass.v8n12p238

Maslach, C., Schaufeli, W. B., \& Leiter, M. P. (2001). Job burnout. Annual review of psychology, 52(1), 397-422. https://doi.org/10.1146/annurev.psych.52.1.397

May, D. R., Gilson, R. L., \& Harter, L. M. (2004). The psychological conditions of meaningfulness, safety and availability and the engagement of the human spirit at work. Journal of occupational and organizational psychology, 77(1), 11-37. https://doi.org/10.1348/096317904322915892

Mayfield, J., \& Mayfield, M. (2007). The effects of leader communication on a worker's intent to stay: An investigation using structural equation modeling. Human Performance, 20(2), 85-102. https://doi.org/10.1080/08959280701332018

McManus, J. (2015). Strategies to build trust and improve employee engagement. International journal of management \& information systems, 19(1), 37-42. https://doi.org/10.19030/ijmis.v19i1.9056

Mone, E. M., \& London, M. (2019). Employee Engagement through Effective Performance Management - A practical guide for managers (2nd ed.). Routledge; ISBN-10: 1138648280

Mone, E., Eisinger, C., Guggenheim, K., Price, B., \& Stine, C. (2011). Performance Management at the Wheel: Driving Employee Engagement in Organizations, Journal of Business and Psychology, 26(2), 205-212. https://doi.org/10.1007/s10869-011-9222-9

Mongkolworakitchai, N. (2016). The leadership of the director and the engagement of high performance teachers in the schools of the Saint Gabriel Foundation, Thailand. Human Resource and Organization Development Journal, 8(1), 75-101.

Motyka, B. (2018). Employee engagement and performance: a systematic literature review. International Journal of Management and Economics, 54(3), 227-244. https://doi.org/10.2478/ijme-2018-0018

Mwangi, R. W., \& Waithaka, P. (2018). Organisational culture and performance of public universities in Kenya. International Academic Journal of Human Resource and Business Administration, 3(2), 314-33.

Nuttin, J. (1984). Motivation, Planning and Action. Erlbaum, Hillsdale, NJ.

Osborne, S., \& Mohammad, M. S. (2017). Effective Employee Engagement in the Workplace. International Journal of Applied Management and Technology, 16(1), 50-67. https://doi.org/10.5590/IJAMT.2017.16.1.04

Parker, S. K., \& Wall, T. D. (1998). Job and work design. Organizing work to promote well-being and effectiveness, Sage, London.

Patti, R. J. (1987). Managing for service effectiveness in social welfare organizations. Social Work, 32(5), 377-381. https://doi.org/10.1093/sw/32.5.377

Pfaff, E., \& Huddleston, P. (2003). Does it matter if I hate teamwork? What impacts student attitudes toward teamwork. Journal of Marketing Education, 25, 37-45.

Proctor, T., \& Doukakis, I. (2003). Change management: the role of internal communication and employee development. Corporate communication: an international journal, 8(4), 268-277. https://doi.org/10.1108/13563280310506430

Ravikumar, T. (2013). A Study on the impact of teamwork, work culture, leadership and compensation on engagement level of employees in MSMES in India. International Journal of Advanced Research in Management and Social Sciences, 2(8), August 2013.

Robertson, I. T., Birch, A. J., \& Cooper, C. L. (2012). Job and work attitudes, engagement and employee performance: Where does psychological well-being fit in? Leadership \& Organization Development Journal, 
33(3), 224-232. https://doi.org/10.1108/01437731211216443

Robinson, D., Harley, A., \& Lee, D. (2005). How to integrate culture and employee engagement. Strategic HR Review, 4(6). Melcrum Publishing, UK.

Robinson, D., Perryman, S., \& Hayday, S. (2004). The drivers of employee engagement. Report-Institute for Employment Studies: UK.

Russell, J. (2010). Career coach: Recognition not only boosts employees, but can also give a lift to the bottom line. The Washington Post. from http://www.washingtonpost.com/wpdyn/content/article/2010/10/22/AR2010102205919.html

Saks, A. M. (2006). Antecedents and consequences of employee engagement. Journal of Managerial Psychology, 21, 600-619. https://doi.org/10.1108/02683940610690169

Schalock, R., \& Bonham, G. (2003). Measuring outcomes and managing for results. Evaluation and Program Planning, 26, 229-235. https://doi.org/10.1016/S0149-7189(03)00027-2

Schaufeli \& Bakker, A. B. (2004). Job demands, job resources and their relationship with burnout and engagement: A multi-sample study. Journal of Organizational Behavior, 25, 293-315. https://doi.org/10.1002/job.248

Schaufeli, W. B., Martinez, I. M., Pinto, A. M., Salanova, M., \& Bakker, A. B. (2002). Burnout and engagement in university students: A cross-national study. Journal of cross-cultural psychology, 33(5), 464-481. https://doi.org/10.1177/0022022102033005003

Shaffer, J. (2000). The leadership solution. New York: McGraw-Hill.

Singh, P. (2008). Job analysis for a changing world. Human Resource Management Review, 18(2), 87-99. https://doi.org/10.1016/j.hrmr.2008.03.004

Smithikrai, C. (2019). Antecedents and Consequences of Work Engagement among Thai Employees. The Journal of Behavioral Science, 14(3), 14-31.

Snyder, R. A., \& Morris, J. H. (1984). Organizational communication and performance. Journal of Applied Psychology, 69(3), 461-465. https://doi.org/10.1037/0021-9010.69.3.461

Sowa, J. E., Selden, S. C., \& Sandfort, J. R. (2004). No longer unmeasurable? A multidimensional integrated model of non-profit organizational effectiveness. Non-profit and Voluntary Sector Quarterly, 33, 711-728. https://doi.org/10.1177/0899764004269146

Sparrow, P. (2008). Performance management in the U.K. In A. Varma, P. S. Budhwar, \& A. DeNisi (Eds.), Performance management systems: A global perspective (pp. 131-146). New York: Routledge.

Stone, M., \& Cutcher-Gershefeld, S. (2001). Challenges of measuring performance in non-profit organizations. In P. Flynn \& V. Hodgkinson (Eds.), Measuring the Impact of the Non-Profit Sector (pp. 33-57). New York: Kluwer Academic/Plenum.

Suzy, F., Spector. P. E., \& Miles, D. (2001). Counterproductive work behavior (CWB) in response to job stressors and organizational justice: Some mediator and moderator tests for autonomy and emotions. Journal of Vocational Behavior, 59(3), 291-309. https://doi.org/10.1006/jvbe.2001.1803

Swarnalatha, C., \& Prasanna, T. S. (2013). Employee engagement: The concept. International Journal of Management Research and Reviews, 3(12), 3872.

Thayer, S. E. (2008). Psychological climate and its relationship to employee engagement and organizational citizenship behaviors. Retrieved from http://www.academia.edu/6709919/Employee Engagement and Organizational Effectiveness the Role of Organizational Citizenship Behavior.

Tricoles, R. (2012). Fairness in workplace key to employee, organizational health. Fabbs Foundation. Retrieved from http://www.fabbs.org/fabbs-foundation/education-resources/sciencecommunications/fairness-at-work-key-to-e mployee-and-organizational-health/

Tsai, W. C., \& Tai, W.T. (2003). Perceived Importance as a Mediator of the Relationship between Training Assignment and Training Motivation. Pers. Rev., 32, 151-163.

Tumarkin, O. (2019). Measuring Employee Morale - Management Quality Indicator. Retrieved from https://bscdesigner.com/measuring-employee-morale.htm 
Upadhyay, D., \& Anu, G. (2012). Morale, welfare measure, job satisfaction: The key mantras for gaining competitive edge. International Jour. of Physical and Social Sciences, 2(7), 80-94.

USA Hockey (2006). Teamwork. Retrieved 10 December, 2006 from http://www.usahockey.com

Van Vuuren, M., \& Elving, W. J. L. (2008). Communication, sense making and change as a chord of three strands. Corporate Communications: An International Journal, 13(3), 349-359. http://dx.doi.org/10.1108/13563280810893706

Vuong, B. N., Tung, D. D., Hoa, N. D., Chau, N. T. N., \& Tushar, H. (2020). An Empirical Assessment of Organizational Commitment and Job Performance: Vietnam Small and Medium-Sized Enterprises. The Journal of Asian Finance, Economics, and Business, 7(6), 277-286. https://doi.org/10.13106/jafeb.2020.vol7.no6.277

Wagner, E. (2008). Change beyond organizational transformation: Use of multipliers in change communication: How credible personal communication can make change effective. Springer-Verlag Berlin Heidelberg.

Welch, M. (2011). The evolution of the employee engagement concept: communication implications. Corporate Communications: An International Journal, 16(4), 328-346.

West, M., \& Dawson, J. (2012). Employee engagement and NHS performance. London: King's Fund.

\section{Copyrights}

Copyright for this article is retained by the author(s), with first publication rights granted to the journal.

This is an open-access article distributed under the terms and conditions of the Creative Commons Attribution license (http://creativecommons.org/licenses/by/4.0/). 